\title{
1. Risk, uncertainty and class in European societies
}

The financial crisis of 2007-08 and its continuing aftermath have exposed the lives of many working people in the advanced societies to higher levels of economic uncertainty than they had been accustomed to experiencing in recent decades. For some observers this immediately suggests a need for policies that will reduce insecurity, perhaps by protecting workers from losing their jobs. But others contend that economic insecurity is just the other side of the coin of flexibility, and that it is only through some people losing their jobs and having to find others, or accepting lower wages, that the economy can move back to a level of successful innovation; and that without that vital step, everyone's job is insecure, including those ostensibly protected by employment protection law. But others again claim that exposing large numbers of working people to a high level of insecurity will undermine their capacity to consume, which will in turn undermine attempts to revive the economy. Against this it can then be contended that economic recovery does not have to depend on domestic consumers, but can be fuelled predominantly by exports of goods and services. The outcome of the conflict will vary from country to country. This does not mean that governments and others have ample scope for choosing what paths they will take. At any one point in history an individual country brings with it a set of inherited balances of social and political forces, institutional endowments and a location in international networks. These factors are likely to condition the pattern of responses that it makes.

The purpose of this book is to explore the relevant institutional capacities for confronting these questions of the countries of the European Union (EU) and European Economic Area (EEA), with some reference to certain leading extra-European economies: Japan, the Russian Federation and the USA. Contemporary Europe combines some highly developed, high-income countries in its north west; some slightly less wealthy ones in its south west; and some middle-income countries in the former state socialist bloc to the east. Together they provide a diversity of income levels and institutional types in which the issue can be explored.

The question at stake is not a functionalist one about which technical means best provide working people with security, but instead is deeply 
conflictual. In principle, the employers of labour seek the most flexible possible workforce, one whose anxieties about uncertainty are of no more relevance than that of a piece of machinery. That was often the reality of the relationship in the early years of industrialization; and it has returned to twenty-first-century capitalism in such forms, increasingly popular among employers, as the zero-hours contract. Here, workers are paid only for those hours when the employer calls on their labour; but they have to be in a state of readiness whenever that call comes and therefore cannot easily take on additional jobs to cover them for periods when the employer does not want them and their income sinks to zero. This is by no means the only type of labour contract that employers want. For many kinds of work they value experience, accumulated skill and loyalty; there is then a coincidence of interest between employers and employees in continuity and security. However, in a competitive market individual employers will always be seeking ways in which they can maximize flexibility by reducing their commitment to particular kinds of workers. This incentive has to be traded off against the value of stability in certain contexts. If all firms competing in the same product market face the same patterns of labour needs, there will be no market disadvantages to those who decide to grant security of employment to certain kinds of workers. But it must be assumed that all firms are constantly seeking ways of achieving their production goals with more flexible workforces.

At the level of a national economy the clash between employers' search for flexibility and workers' search for security takes a different form. Particularly where there is formal democracy, governments have two relevant requirements. First, they have to be sensitive to popular discontent at extreme insecurity. Second, they are concerned that the population has a capacity to consume, that is, make purchases, with confidence; the less secure that a working population feels, the less confidently it can spend money. The nation state is the political level at which the tension between flexible labour and confident consumers bites, because it is here that the most intense elections are fought and where economic accounts have to be balanced. The EU is a part-way supra-national stage in this process; in other regions of the world there is little beyond the nation state. This political engagement in the issue means that an analysis of the positions of labour and capital is not enough to exhaust its study. We have to add social policy.

Finally, the tension appears at a different level when capital confronts its own simultaneous needs for flexible workers but confident consumers to whom it can sell its products. In this study we shall primarily present the issue of labour security from the perspective of this tension, both in 
general between capital and labour and nationally in labour market and social policy.

This is not a general study of varieties of capitalism, nor of the causes of economic success and failure, nor a detailed study of security policies. Our task is very specifically to examine the tension between consumption and labour flexibility, and the ways in which different balances of power between capital and labour affect the ways in which it is resolved, and the forms of governance that provide these different outcomes.

The present chapter examines the broad concepts within which the study will be conducted. Chapters 2 and 3 then provide the more immediate operational framework for the research. Chapters 4 to 6 present the evidence. Chapter 4 considers the extent to which the conundrum can be resolved by consumers and workers being different sets of persons. Chapter 5 examines ways in which a population's consumption possibilities can be separated from its labour income. In Chapter 6 we explore the functioning of welfare state institutions that might ease the tension between flexibility in the labour force and confident consumption within the labour market itself. From this account will emerge certain provisional conclusions about the characteristics of the majority of the countries being considered. These are brought together in Chapter 7 within the overarching theme of the different forms of governance available. Chapter 8 then looks at overall trends in these characteristics and their wider implications.

\section{FROM SOZIALPOLITIK TO INDUSTRIAL RELATIONS - AND BACK}

We must first examine the range of policy areas that need to be taken into account in such a project. For several decades now the study of labour issues has been a specialized field, rather cut off from the rest of sociology and economics. It used to be known as 'industrial relations', an essentially Anglo-American construction, and concentrated on relations between employers and organized labour in manufacturing, mining, construction, and a few other sectors where trade unions and collective bargaining were strongly established. University departments and journals used the phrase 'industrial relations' in their titles. The importance of trade unions began to decline in some countries after the 1970s, partly because economic change led to a decline in industrial employment in the core countries, partly because governments in the UK, the USA and elsewhere began expelling unions from the organizations that they would consult over policy in relevant areas. The term 'industrial relations' became embarrassing to some university managers, and by the 1980s departments started 
to be renamed as 'human resource management'. This narrowed the field even further to a management perspective on how to get the most effective work out of employees.

Meanwhile, however, the subject of labour organization was requiring exactly the opposite: a broadening of focus. 'Industrial relations' itself had long seemed too narrow for many continental European scholars, accustomed, until forced to come to terms with Anglo-American domination of the social sciences, to speak of politique sociale, Sozialpolitik and similar terms (Barbier 2008a). While these can be translated easily enough as 'social policy', the English term has always had a narrower meaning, referring to certain institutions of the welfare state or even more narrowly to social benefit payments. The equivalents in other European languages described both that area and the whole field implied by 'industrial relations'. The unifying principle was that both had been seen as addressing the great question sociale (or soziale Frage) of the late nineteenth and early twentieth centuries: how to incorporate the industrial working class within civil society. The social settlements around the place of labour in society that had been established around the end of World War II in most of western Europe - somewhat earlier in Scandinavia and (though then more temporarily) in the USA - included the establishment or consolidation of both welfare states and industrial relations regimes that recognized certain social rights of workers' representatives to participate in settling terms and conditions of work. The two policy fields then went their separate ways, as it seemed that the task of class incorporation had been achieved, leaving some important technical policy issues, addressing which required increased specialization among academics, policy makers and practitioners.

For much of the second half of the twentieth century the main public policy concern in the industrial relations field was containment of the inflationary tendencies of Keynesian demand management. This presented a number of classic collective action problems, which provided the main analytical frame for academic study (Crouch 1993: chapter 2; Olson 1982). Social policy in its own new specialized sense sometimes played a subsidiary role; elements of welfare policy provided material for agreements between governments and unions over how to manage inflation, but it was mainly seen as a different subject, to be studied with different if related analytical tools. While there was always a diversity of employment statuses, in general that of the male, full-time, dependent employee with an indefinite work contract was dominant, as self-employment and various forms of job tenure associated with agriculture declined. Policymaking in all these fields was largely contained at the level of the nation state. Economic growth was seen as entirely beneficial, and questions were 
not asked about the environmental impacts of the kinds of activity that produced such growth.

The major inflationary crises of the 1970s brought industrial relations and social policy together again, but in a very specific way. Both wage bargaining in a context of politically guaranteed full employment and governments' alleged tendencies to finance improving social welfare provision through money creation rather than taxation were regarded as major factors in inflation. During the 1980s and 1990s - the timing varies in different countries - public policy changed. Governments turned to monetary as opposed to demand management policies, creating new environments in both policy areas. For labour issues this approach implied improving flexibility by intensifying insecurity without compensation, drawing much from the so-called 'supply-side revolution' in the analysis of the labour market in economic theory. Beginning as the revolt against taxation from the US centre-right known popularly as 'Reaganomics', in economic writing this was a more general concern for looking at the conditions of labour supply, replacing the earlier concern of Keynesian policies with levels of demand in the economy (Canto et al. 1983; Roberts 1984). This became part of the more general economic policy orthodoxy known as neoliberalism, demanding a market economy free from constraints by governments, regulation and such organizations as trade unions. The initial impact of all this was to reduce the importance of both industrial relations and social policy, but the longer-term consequences have been rather different, and have brought about a need to bring the two bodies of knowledge fully together once more.

The business of industrial relations shifted away from inflation management to being a series of deals and conflicts over how the burdens of economic uncertainty should be distributed, and through what forms of social policy and employment contracts. In this process several institutions have engaged in new practices; and there has been a new diversity of employment forms and tenures. Social policy has become reintegrated with employment and industrial relations practices, being central to the distribution and redistribution of uncertainty. A certain wheel has turned full circle, returning us to an ensemble of policies reminiscent of that of the late nineteenth century's, though with very different content. As we shall see in subsequent chapters, this has happened partly through the rise of the social investment welfare state, including active labour market policy and childcare support for working families (Hemerijck 2012a), and also through the reappearance of social policy issues in industrial conflict; in some countries, particularly France, major strikes have tended to be about pensions rather than pay. In most of Europe, these changes have taken place during, and under pressure from, a period when economic 
growth could no longer be taken for granted. This then raises the priority of growth as a policy objective, but at precisely the moment when environmental concerns have also made it a priority to consider qualitative as well as quantitative characteristics of growth.

Countries in central and eastern Europe had a different experience during the western Keynesian period, but the state socialist regimes also, in their way, protected working populations from economic uncertainty. Today these countries share a similar policy agenda to their western counterparts, but usually with far higher levels of uncertainty and within very different institutional contexts.

By 2008, when the Anglo-American banking crisis triggered a global financial recession and a specific crisis in some countries of the Eurozone, the terms of policy conflict changed again. The primary cause of the linked crises was the behaviour of banks in a deregulated global financial market, and therefore it was a crisis of the dominant neoliberal economic model. However, because the solution adopted was for states to use public money to rescue the banks, pressure was placed on public finances that could be eased only by cutting back on other state expenditure, especially social policy. Further, in several countries governments had financed welfare state spending through bank borrowing rather than through adequate taxation. These loans now had to be repaid, at the expense of very extensive reductions in social spending. Further still, business interests were able to argue that they could recover from the deep recession only if they were freed from regulation, particularly labour regulation, but also other areas of social and environmental policy. Without such changes there would be deepening unemployment and reduced de facto labour security. In this way, a crisis caused by neoliberal deregulation (of financial markets) produced a pressing demand for more neoliberal deregulation, and a renewed challenge to social policy and labour market institutions (Mirowski 2013).

\section{RISK, UNCERTAINTY AND DEBT}

Policies for protecting workers from uncertainty have therefore become matters of intense disagreement and conflict. Measures that provide people with security in their working lives are often seen as ipso facto reducing their flexibility: as limiting employers' ability to fire employees, reduce their incomes or change their working conditions in order to adapt to competitive pressures. If employers cannot do these things, it is argued, they will lose business and therefore the capacity to employ. During the Keynesian period governments accepted an obligation to maintain the level of employment - or, rather, of male employment. While democratic 
governments have never really been able to escape from being held responsible by voters for problems of unemployment, the decline of the Keynesian priority has had a dramatic impact on the perspectives of trade unions and employers in their negotiations. The potential impact of their actions on employment levels has become the central issue in much of what they do. Employment has become what Évelyne Léonard has called 'the new general equivalent', or the currency against which all developments in collective bargaining and labour market policy are measured (Léonard 2001). Streeck (2008) makes a similar but broader point when he argues that citizenship and social policy expectations are being reformulated until labour is required to accept all manner of risks just to get employment. This does not mean that bargainers and policy makers are then called upon to try directly to safeguard employment by such measures as strict employment protection laws; far from it. Such direct measures are often seen as reducing flexibility and, in anything more than the short term, as harming employment rather than safeguarding it.

Many discussions of labour market and social policy, especially in the EU, have started from an assumption of this tension between flexibility and security (European Commission 1993, 2005, 2006, 2007; OECD 1994). However, the appearance of policy combinations that optimize both demonstrates that constructive and positive compromises can be envisaged between these two forces. Interest in Europe has concentrated on 'flexicurity', based initially on important policy initiatives in Denmark and the Netherlands (Bredgaard et al. 2007, 2008; European Commission 2007; Jørgensen and Madsen 2007; Klammer and Tillmann 2002; Muffels and Luijkx 2008a, b; Wilthagen and Tros 2004). During the crisis itself there was a growth of temporary agreements that maintained workers' jobs in exchange for reduced working hours and pay - reflecting a joint interest between employers wanting to hold on to valuable skilled workers and the workers' own need for job stability (Glassner et al. 2011; Marginson et al. 2014). In fact, the overall range of policies and practices involved in the reformulation of the balance between flexibility and security is considerably more extensive than this (Burroni and Keune 2009; Crouch and Keune 2012; and see Madsen 2009 for the Danish case in particular). These various policies are however usually seen as compromises. At least among policy makers there is a strong assumption that markets would be more efficient if they were not troubled by these demands for security. This became evident in 2012, when, as noted above, faced with a need to tackle urgent economic problems in Ireland and southern European member states of the European single currency, the EU demanded simple neoliberal market flexibility. This could be seen particularly in the detailed conditions imposed on Greece in exchange for its bailout (Government 
of Greece 2012). All 'flexicurity' talk of combining labour flexibility with new kinds of security that would help upgrade the economy was thrown out of the window.

Flexibility and security relate asymmetrically to the problem of market externalities. Flexibility is by definition a market variable, as it implies requiring labour to adjust to market demands. Self-employed workers adjust directly to market forces; employed workers' adjustment is filtered through managerial hierarchies and is possibly negotiated by trade unions. Security, defined here in terms of workers' desires or needs for protection from uncertainty, is only incidentally reflected in market forces. It will be such, for example, when employers want to ensure that they retain skilled workers in order to save recruitment and training costs, or to keep workforces together during temporary downturns. But in general, workers' concerns for their security are seen as external to the market; this is why they appear in most economic literature as a constraint on it, and why responses to them are seen as a problem. However, if one accepts that the concern for protection from uncertainty is a legitimate human aspiration, the problem can be redefined as a market failure to deal with an important externality. That is of course precisely what had happened in the past, as over the years a range of public policies were developed to provide protection against uncertainty: public pensions and social insurance, protection of employment legislation, minimum wages, rights of trade unions to represent employees against the power of employers to dispose of their labour (Freedland 2006; Knegt 2008). For much of the twentieth century the gradual accretion of these protections was seen as social progress, recognition that labour markets potentially embodied some undesirable externalities. This changed during the last quarter of that century, protection coming increasingly to be seen, like all other attempts to withstand market forces, as self-defeating.

However, we can take discussion beyond this simple opposition between the market and restraints on it. The externality we have identified can be subdivided into a private and public component. To the extent that the consequences of insecurity are contained within the private lives of the individuals affected, and dealt with in some way or another within individuals' domestic circles, they can be regarded as of no public importance. But there are several ways in which they acquire such importance and therefore become a matter of public policy. First, if labour insecurity translates into low consumer confidence, or even civil discontent, governments may become concerned at inadequate demand. This is a problem defined partly in economic rather than social terms, but it is still a market externality, as the market cannot provide the means of its own existence. Second, workers, if the numbers concerned are large enough, are able to 
turn their private anxieties into public questions. Only in democracies can they do this by placing issues on the electoral agenda; but in democracies and authoritarian regimes alike they might respond by threatening social order. Under these circumstances governments, and other agencies responsive to public problems, try to balance the externality perceived as a market failure with a need also to strengthen the market in the interests of pursuing flexibility. Only rarely therefore has there been a solution to the antagonism between flexibility and security through the total triumph of the former.

This formulation may seem to imply that the employers' 'side' in the conflict is represented by a demand for flexibility in a context governed by the market, while the employees' 'side' constitutes a demand for security protected by public policy and perhaps trade unions. The former is an oversimplification. First, the 'employer' is often a public authority and not a property owner. More importantly, employers of all kinds depend on public protection as much as do employees. The right to own property requires definition in law and an ability to call the forces of order to enforce it. Also, capital may call on state aid and protection at least as much as labour when it gets into difficulties. Such aid will not necessarily be offered, and the principles for offering it are usually not as strictly defined as those for labour protection, but from time to time firms are rescued or their conditions eased by government. It had been widely considered that such interventions had been ended by the same wave of neoliberal thinking that defined employees' rights as a problem rather than a social advance. But the financial crisis of 2008 demonstrated exactly the opposite. So important had the financial risk-trading sector of the economy become, that the failure of major players in it was seen as a massive market externality against which governments had to act. Banks had very successfully defined their private need for reduced uncertainty as a collective one.

\section{Uncertainty and Risk}

For the great majority of humankind economic uncertainty is a source of deep anxiety and awareness of helplessness. For a fortunate and sizeable minority in wealthy countries it is a problem against which there are various though limited possibilities for protection, but also a potential source of opportunities. For a tiny minority in all parts of the world uncertainty constitutes a chance to make enormous gains through skilful investments in markets at risk. It is not surprising that in a world of rapid and massive change and therefore uncertainty, inequality within and between nations has risen steadily. That rise has been intensified as the post-2008 
bank rescues protected that tiny minority from catastrophic errors in its risk calculations.

These inequalities in the ways in which uncertainty presents itself to people in different circumstances come about through differential capacity to translate uncertainty into risk. As Knight (1921) established long ago, risk is calculable uncertainty in terms of probability theory. Being calculable, risks can be traded. There are therefore markets in risk, and the estimation, trading and management of risk in this sense have become major activities of the financial sector of many economies. People in different economic circumstances stand in very different relationships to these markets. To access them one needs both wealth (to deploy in risk trading) and knowledge (to know how to go about doing so). In general, the more wealth a person owns, the stronger his or her incentive either directly to acquire that knowledge or to pay for the professional advice of those who have it. Therefore, the more wealth one has, the more one is likely to gain from engaging in risk trading (though there will always be a small number who are either very unlucky or very ill advised, and who make major losses).

Most people do not have such wealth. Some individuals are rich enough to engage in a little investment activity and gain minor rewards from risk trading, but they, like the vast numbers of those who have no tradable wealth at all, will primarily depend for their standard of living on earnings from work, either their own or that of family members or persons otherwise close to them. Limiting our attention to people living in relatively advanced economies, economic uncertainty is likely to affect them through potential loss of a job or deterioration in the rewards it brings, or potential loss of capacity to work through health problems or old age. These are forms of uncertainty that threaten to knock people down from the levels of living they have achieved. There will also be uncertainties around attempts to raise one's level of living: applications for new jobs, or promotions, or attempts to expand a business. These are positive uncertainties and of less interest to us than the negative ones, provided failure in the attempt to improve leaves the person no worse off than before.

If negative uncertainty is a 'bad', we should expect to see many attempts at reducing its implications; only its implications, not uncertainty itself. The problem can never be resolved by creating certainty, as it is not possible to provide this quality in economic life without killing off all innovation and change. This was more or less the social policy deal offered by governments in the Soviet bloc, and it ended in disaster. Instead, steps are taken to manage or govern uncertainty. This might be done through the market, as in the risk trading described above, or through state action, corporate practice, the actions of trade unions or the work of families. 
Actors remain free to choose to take risks; an environment of economic security protects them only from the negative consequences of risks that are not of their own choosing.

The Knightian concept of risk as tradable uncertainty still leaves a degree of uncertainty that cannot be calculated (or which is left over when the laws of probability have been applied), or which results when risk calculations fail - as they did spectacularly in the global financial markets in 2008. This residual uncertainty, that part of uncertainty that either cannot be marketed or which is vulnerable to market failure, is therefore equivalent to what we have termed here the market externality of risk.

It was noted above that for the best part of the twentieth century the protection of labour from uncertainty was seen as a justified response to this externality, but that this perception changed among increasing numbers of observers and politically influential interests. This change has been paralleled in the predominant account given in the recently developed sociology of risk (Beck 1986; Luhmann 1991). This maintains that a change took place at a certain point in the development of modern societies, when large numbers of people started to change their approach to uncertainty. Instead of seeing it as something menacing, to be either avoided or accepted, people came to regard it as something they could use and turn into calculable opportunities. In other words they could turn it into risk: hence Beck's concept of die Risikogesellschaft, or the 'risk society' as a way of characterizing modern societies. Potential social policy implications of this were perceived by a number of scholars (Bonoli 2007; Giddens 1994, 1998; Häusermann 2012; Taylor-Gooby 2004), who distinguished between 'old' and 'new' social risks. Old social risks were those that had been designed to compensate the working-class population of industrializing societies against basic uncertainties of the kind we have considered above: insurance against unemployment, ill health and old age; trade union rights and employment protection. These were essentially passive forms of protection that assumed populations who could do little to improve their situation, suited to the rigid hierarchies of class society. New social risks (NSR) were those that could comfortably be accepted by workers in affluent post-industrial societies, with more flexible, less hierarchical work organizations, declining class structures and increased social mobility, who did not need protection from the old risks. These people aspired to opportunities; for them, uncertainties were becoming risks that they could use. This does not mean that risks had become pleasant experiences. Post-industrial societies still presented their citizens with difficulties and challenges, but they were those typical of wealthy, classless populations: the new social risks were therefore population ageing and associated care problems; the balance of family life and 
female employment; risks that one's educational qualifications will not facilitate employability.

The NSR approach enables us to take account of major changes that have affected advanced societies since the major reformulation of welfare state arrangements around World War II. Important examples are deindustrialization, female labour-force participation, increased mass longevity (and hence population ageing), flexibilization and an increased variety of employment relationships. It shows how these changes have created new vulnerable groups; and it also shows that welfare policies have changed, bringing increasing diversity rather than convergence across Europe. Perhaps its most important contribution has been to identify the intricate set of relationships that link care policies (for children, the elderly and other vulnerable groups) to women's labour-force participation, and to family structures, breaking down the divisions that led to these being viewed as separate areas during the heyday of male-breadwinner, industrial economies (Esping-Andersen 1999).

However, the insistence of much analysis of this kind that the 'old' problems of class society have been transcended leads its proponents to overlook or discount some major issues. As argued by Crouch and Keune (2012), NSR analysis sees welfare states as having to be reoriented to reflect changed socio-economic circumstances, these circumstances themselves being taken for granted as fixed. People must adapt to the market rather than reduce their exposure to it; the individual is seen as responsible for ensuring his or her own employment and can choose from the jobs offered, become self-employed or seek forms of education that will improve his or her employability. Unemployment is thus an individual problem to be addressed through education, though with some collective help through active labour market policies (ALMP). The most obviously weak point in this reasoning is that it assumes that, apart from ALMP, ordinary individuals have a capacity to predict and identify the kinds of job for which they should prepare themselves in future, although in reality even specialist job-research institutions have difficulty making such predictions. The NSR approach also fails to take into account that it is often employers, managers and financial capital that drive and define the uncertainties that emerge in the new circumstances; these are not 'natural' phenomena transmitting technical information about an inevitable reality. There is some capacity for choice of strategies, including their effects on welfare and uncertainty.

A conflict of interests between classes is therefore obscured by the NSR school. This is curious because risk, the core concept of the approach, is, as noted above, subject to extremes of inequality related to the most fundamental of class concepts: property ownership. The risks related to 
the work and welfare of the mass of the population are seen as a kind of sealed box bounded by social and labour market policy. Their connections to the trading in risk in which the wealthy can engage are simply not perceived. There is a continuum of risk extending across whole societies, and the sociology of risk needs to take account of it all. For example, the ability of moderate-income families to cope with insecure labour markets may be considerably improved if they can take out a 120 per cent mortgage on their home and use it to fund their daily consumption. But their ability to do that will depend on traders in financial markets being able to make money from selling such unsecured loans. These traders might be more willing to take on such risks if they have secure expectations of high earnings in other markets. They might be able to do this - and this is precisely what they have done - by investing in pension funds that do not offer pensioners guaranteed rates of benefit, but benefits that depend on stock-market valuations at the moment of their retirement. These latter, 'defined contributions' pensions throw the risk of pension inadequacy on to the pensioner, reducing it for investors (Ebbinghaus 2012; Whiteside 2014). These arrangements will have implications for old-age poverty in future years. As those so wealthy that they can make high earnings by extracting the tradable risk from uncertainty carry out their operations, they pass the untradeable bundle of uncertainty down until it rests with those unable to do the same.

\section{Risk and Class}

Relationship to the risk/uncertainty mix is a classic class relationship because it is very closely related to relationship to property ownership. Far from class in this sense declining in post-industrial societies, it has become increasingly important. This results from the central role of the financial sector, the area of the economy where pure wealth counts more than anywhere else. The fact that, compared with the first half of the twentieth century, far more people own some property does not reduce this. There is a fundamental difference between liquid and illiquid assets. The inequalities between a family whose property consists almost entirely of the home in which it lives and one with millions invested in stocks and shares is greater than is expressed by the quantitative difference. There are severe limits to the risks one can take with one's sole residential property, and therefore to the interest rates that one can expect to earn, compared with liquid assets that one is using just for investment. Attempts to transcend this problem in the USA and elsewhere by encouraging remortgaging of such property, the resulting debt then being traded as a liquid asset, was a proximate cause of the 2008 crisis. 
When observers talk of a decline in class in post-industrial societies they mean the decline in clearly marked social groups that have accompanied the decline of the factory as the paradigm of hierarchical social relations. In fact there has never been a society in which a majority (even of male persons) had lives related to factories, but the social hierarchy of the factory projected a powerful image to societies accustomed to the even more rigid hierarchies of post-feudal rural economies. The paradigmatic factory had:

- some owners who possessed the property, and whose income was derived from profits from the risk of their investment;

- some managers and professionals, who did not own extensive property, but who were highly rewarded because of their relationship of trust with the owners, and who therefore could accumulate wealth over time;

- various grades of clerical and other support staff to the managers working alongside them in offices and sharing some of the basis of trust, but on relatively lower earnings and unlikely to accumulate much wealth;

- various grades of manual workers, whose incomes depended on their skill level, enabling those with the highest skills gradually to accumulate some wealth.

The social segregation between office (where workers typically wore suits and had white collars) and factory (where workers wore overalls with blue collars to protect themselves from a typically dirty environment) produced the sociocultural reality of a distinction between middle and working classes (factory owners being perhaps a dimly perceived small upper class, if they were wealthy enough). It also represented a broad political hierarchy of power and authority, proceeding from owners through successive levels of management on to the factory floor. There was a rough link between this politico-sociocultural reality and different levels of property ownership, giving a similar very broad pattern of three classes. The matching was imperfect, particularly because the lower levels of office workers earned less and exercised less power at work than skilled manual workers, despite being on the other side of the office/factory divide. In time however these lower level office workers became primarily female, and women were simply disregarded in images of class society, whether in popular imagination or professional sociology (Crompton 1989; Goldthorpe 1983). Women 'took their class' from their husband, so in turn women's occupations - even those of unmarried women - dropped out of class analysis. While this was unacceptable for the study of the class 
position of occupations, it had some logic for class as related to property. To the extent that people lived in families, occupational earnings would contribute to a common pool of wealth. If, as was usually the case, husbands earned more than their wives, their earnings would contribute more to that stock.

Class in this sense could be simultaneously clear and vivid, with profound political implications, and very vague or rough. As already noted, only a minority ever worked in factories in any capitalist economy, other occupations finding their place in class society through analogy. For example, schoolteachers resembled in their educational (and usually family) background the professionals (engineers, accountants) in the factory office, and had broadly similar if lower earnings. They were assimilated to the same class.

Also, wealth and earnings form a continuum, while classes form clearly separated categories. Mapping the former on to the latter always produces distortions and ambiguous cut-off points. It has long been argued (Giddens 1973; Weber 1919) that this was a distinctive feature of capitalist society, feudal and post-feudal forms of society coming, as it were, with ready-made, really existing hierarchies of rank. This is a profound misconception of those societies. Pre-industrial societies had highly complicated continua of land ownership, trading wealth and earnings from labour. What appear to be the clearly demarcated classes or estates of those societies represent attempts by kings and aristocrats to impose an order on the continua, often in order to protect their own position as the formal apex of the system despite the accumulation of superior levels of wealth by some bourgeois. Sometimes they might exclude whole categories of persons from certain activities (e.g., Jews from land-holding), but often all that they could do was to define artificial categories that gave different levels of rights and often implied important cultural distinctions, but not the reality of wealth ownership. A person without an inherited aristocratic position could be excluded from using certain titles, from participating in certain kinds of decision-making or even from wearing certain garments. But there was a constant tension between the two realities of social differences that resulted from divisions defined by political authority and those that emerged from various forms of property ownership. The former made broad, fairly clear categories, the latter continua.

Industrial class society was very similar, except that the categories were defined not so much by political authority as by factory owners and managers designing the hierarchies through which they would carry on their businesses, the broad rankings of the factory hierarchy listed above. There was a kind of privatization of class definition. Even this was not entirely true. The modern state and army developed before the modern 
factory as large-scale work organizations, and to some extent furnished models for employers on how to order the hierarchy of a factory. The division between office and factory paralleled that between officers and other ranks in armies. German employers modelled the idea of the trusted manager on the distinctive Prussian state concept of the civil servant (Beamter) (Kocka 1981).

The industrial state took a more active and decisive role in a paradoxical way; not so much by defining manual workers in terms of an absence of rights, but by defining protective rights for them. This development was linked to the rise not so much of political democracy itself as pressure for it or the threat of it. Trade unions and radical, sometimes socialist, political parties were capable of disrupting social and economic order and demanding radical limitations to the power of property ownership. Again, Germany provides the locus classicus, with the Bismarckian welfare state designed to pacify working-class agitation by reducing the degree of economic uncertainty in workers' lives through limited social insurance schemes (Palier 2010c). These and other initiatives took it for granted that employers were in positions of power over their workers, especially manual workers, and that the lives of the latter were characterized by insecurity, and often by poverty. Governments did not wish to change that power relation; indeed, they guaranteed it through the laws of property that made it possible for some people to command the labour of others and to extract profit from the process. They also usually maintained rules for access to the suffrage that defined property and gender rights, marking arbitrary category lines across the continuum of property ownership. But they sought to take some of the sting out of that fundamental inequality through limited legislation for labour rights and social welfare (Knegt 2008; Sinzheimer 1921). The social problem was defined relatively unambiguously as that of urban, male industrial workers and their dependent wives and children. These workers were the ones who might threaten social order through their mass status. Rural workers might have worse living conditions but were rarely successful in organizing protests. Selfemployed workers of various kinds might be even less secure but had virtually no capacity to combine. Some office workers had little chance to provide security against eventual calamities, but usually felt they had more to lose from setting themselves in opposition to the managers with whom they mixed directly and personally within the office. Some or all of these groups were usually excluded from the new policy measures. The question sociale was an essentially urban, industrial, male, manual worker question, and the politique sociale that responded to it also took that form. As a result, and paradoxically, urban industrial class differences were to some extent made legal, and thereby politicized, by measures to offset 
their implications. These measures constituted responses to what came to be seen as the 'old' social risks.

As the second half of the twentieth century progressed, these sharp contours of class society softened in western European societies. The property-less had gained admission to the electorate, reducing the most pointed political definition of class boundaries. In most societies, protective legislation originally limited to manual workers in industry was extended to rural workers, the self-employed and non-manual employees, eventually becoming citizenship rights rather than measures to compensate for subordination and chronic insecurity. With the rise of the various services sectors, employment in industry began to decline, reducing the power of the factory paradigm of class structure. Women joined the paid workforce in large numbers, going in particular to occupations that did not form part of that paradigm. In different but related developments, the growing sophistication and professionalization of the welfare state led to an increasing division between it and labour policies, once inextricably bound together as politique sociale.

As industrial passed into post-industrial society, the universalization of citizenship, the declining sociocultural presence of class following deindustrialization, but then the intensification of class as inequalities of property ownership increased again, all moved this ensemble in different directions. The former two, in their different ways, reduced the importance of class identity and its political salience; the last reinforced its importance but in an invisible, politically insignificant way. Meanwhile, new groups of highly insecure workers in precarious forms of employment were forming a potential new class as a 'precariat' (Standing 1999, 2011). Apart from its acute awareness of their gender aspects, NSR analysis emerges as an unreflective consequence of these developments. The first two processes are seen as having removed the class significance of the role of the welfare state in coping with risk, leaving it to technocratic concerns. The invisibility of the third prevented analysts from seeing the class connections that led from risk trading to the economic uncertainty of working people. And the precariat were relegated to a social problem, not a class.

\section{TOWARDS A NEW APPROACH}

If the NSR school is rooted in certain premises about the mainly benign character of the forces at work in post-industrial economies, then in trying to go beyond the achievements of this school we need to rebalance that assumption of benignity (Crouch and Keune 2012). Rapid change and globalization, as well as the move away from Keynesian demand 
management, have together brought new vulnerabilities to working people's lives, uncertainties that are in the first instance defined and managed by employers and the owners of finance capital. Through their decisionmaking in corporate hierarchies, as well as through trading in risk markets, they have considerable scope to decide how uncertainties, experienced initially as exogenous shocks, will impact on different parts of the population, both within and beyond the labour force. The crude 'old risks' associated with labour's helplessness in the face of major market forces have not disappeared (Rogowski 2008a; Schmid 2008) - only the clearly tangible class structure that enabled these to be voiced and to influence public policy. Social policy, in the once-again expanded sense of all interventions (positive and negative) that come between economic shocks and the lives of working people, now has to be studied in terms of this process, distinctions such as that between old and new risks being secondary to it. This then leads us to examine various phenomena that go beyond the scope of the NSR agenda.

The economic uncertainty of people with limited personal wealth and dependent on their place in the labour market for their security reemerged as a central organizing theme for research through the dialectic over flexibility and security discussed above. But the stance of policy had changed radically since an imperative of protecting workers from insecurity informed earlier generations of social policy. Under the influence of neoliberal ideas, policy in all fields has become increasingly governed by the ideal of the frictionless labour market, in which uncertainty would be resolved and shocks countered through rational actors' adaptation of expectations. Such an approach has little time for contemplating market externalities. Instead, it identifies measures to protect workers from insecurity as impediments to the market, which it then sees as the only force that can in the long term provide a kind of security; attempts to provide it by interfering with the market in order to recognize externalities will be self-defeating. If public policy has a role in this perspective, it is in facilitating the inception of this ideal through remedying certain market failures in order to: maximize labour force participation in order to reduce dependency rates and increase the tax base; improve the capacity of individuals to prepare themselves for participation in the labour market; and increase work flexibility among those within the existing workforce and those outside it. This activating role for policy replaces the protective one (Pascual and Magnusson 2007; Van den Berg and De Gier 2008). Davies and Freedland, who in 1993 were able to remark that employment law was primarily about protecting workers from insecurity, have more recently declared that, at least in the UK, this has changed: employment law is now about fitting workers to the exigencies of the market and maximizing 
labour force participation (Davies and Freedland 1993, 2007; see also Knegt 2008; Rogowski 2008a: 13; Verhulp 2008). They point out, in particular, how legislation that seems to be giving workers new rights (such as laws for the promotion of employment among women or elderly people) is actually about increasing the supply of labour. Policy for skills is about improving potential employees' quality and therefore their employability. One might summarize by saying that, if earlier labour law was concerned with human rights, today's law is concerned with human resources.

The NSR approach is fully consistent with this, though 'pure' neoliberal policy makers are not at ease with it. These latter point instead to the importance of individuals making provision from their own resources to convert the uncertainties they face into financial risk products, through private pension and insurance provision, and other purchases of financial assets. This is the narrow space around which policy debate now revolves: pure neoliberalism versus mixtures of it with strong ingredients of proactive, technocratic social policy.

It was argued above that flexibility stands in a relationship of some tension, not only with the demand of working people for stability in their lives, but also with the dependence on consumer confidence of an economy based on mass consumption. The concentration on the supply side of neoliberal economics has drawn attention away from the fundamental fact that an economy needs both supply and demand. To the extent that labour incomes are an important constituent of demand, and to the extent that consumer confidence is dependent on workers' confidence in the continuity of their income, the tension between flexibility and security may not only be one between the market and the welfare state, but a condition of the operation of markets themselves. Some forms of labour flexibility are therefore unwelcome to employers, if it becomes difficult to sustain continuity of employment among skilled and well-trained staff, or where firms are trying to develop strong corporate cultures. Streeck $(2008,2009 b)$ has argued further that capitalism needs the workforce to be reproduced. The conditions of working life seem to be throwing this in some doubt today, as birth rates decline in many parts of Europe. Business interests may therefore favour 'family-friendly' policies, from public childcare to regulation of working hours (see also Klammer 2013).

The perfect labour market is an impossible dream. It is not possible for economic models to incorporate all shocks. It cannot be assumed that actors in the labour market have adequate knowledge rationally to anticipate likely uncertainties and to be able to turn them into tradable risks. Not all the externalities produced by the labour market can be either incorporated within the market itself or ignored as unimportant. If that is the case, then measures to provide for various kinds of security 
against economic uncertainty may be necessary to sustain the confidence economic, political and social - of labour-market participants in massconsumption democracies. But, of course, measures of this kind then impede the progress towards the perfect labour market.

This dilemma has been recognized by policy makers in two different ways. First, they have found it politically impossible to remove social policy supports for economic security in the way recommended by the economic theory. Second, and more constructively, there is important evidence that some forms of security provision do not seem to impede labour market efficiency but are even positively associated with it. This has now been recognized in the OECD's 2006 follow-up to its 1994 The Jobs Study (OECD 2006), as well as in significant academic research (Amable 2003).

If this was already the case, the search for the perfect labour market was even more thoroughly thrown off course by the financial crisis of 2008. As noted above, this was a crisis at the heart of the neoliberal model of market governance. Financial markets of the Anglo-American type, the type responsible for the crisis, had been seen as the purest expression of what could be achieved by the pure market, with their capacity for perfect anticipation and future discounting through calculated risk-sharing (Fama 1971, 1991). As we shall discuss further in later chapters, these markets have also been directly relevant to the problem of the labour market: instead of depending on social security benefits and job protection, workers could offset their labour-market uncertainty by taking on unsecured loans, the risky character of which was 'lost' by being extensively traded in secondary markets. The consumer spending unleashed by these loans stimulated demand in the economy, further reducing uncertainty. It achieved similar goals to Keynesian demand management, but using market means alone and without recourse to government intervention - a kind of 'privatized Keynesianism' (Bellofiore and Halevi 2009; Crouch 2009).

We now know that this model was not sustainable. First, it is questionable whether the deregulated global financial system really meets the criteria of the pure market. It seems to depend on traders not knowing the dimensions of the risks concealed within the bundles of assets in which they trade, whereas models of the perfect market assume rational actors motivated to acquire perfect knowledge. Second, the rush by governments to sustain the banking system after its collapse made that system dependent on political intervention of a kind completely incompatible with the rules of the market. The model is however surviving; the interests vested in it are too powerful for it to be permitted to collapse (Crouch 2011a). But it can no longer be seen as a pure market solution to problems of economic uncertainty. It is yet another distorted market, itself dependent on 
government regulation and financial support. Whether or not the moral hazard introduced by governments intervening in this way will lead to worse outcomes than if governments had allowed the markets to engage in their own major correction is as yet unknown.

In this context, existing doubts surrounding the search for pure labour markets are doubly reinforced. First, if the financial system can exist only with external public support, should the labour market be expected to be any different? Second, if, in some countries, insecure or flexible labour markets were only feasible because workers had access to sources of credit not dependent on their labour incomes, what was to happen after the collapse of the sub-prime mortgage and other unsecured credit markets? If that system was the market's answer to labour-market insecurity, was it really more cost-effective and efficient than orthodox social policy?

It is therefore necessary to revisit the whole question of labour market uncertainty and the most appropriate measures for reconciling workers' demands for protection from it with the need for flexibility. The crisis in unsecured credit enables us to see that it is not only formal public labour market and social policy that are relevant to attempts to reduce economic security; and we should not assume that unsecured credit has been the only other relevant set of practices. Several other areas of life, such as the family, have also been important, in at least some societies; areas that have not been involved in the central ideological conflict between markets and public social policy.

Policy makers, including senior managers of large corporations, have not been presented with the simple possibility of tearing down protections that they had come to see as inhibiting economic performance, but they have been required simultaneously to provide alternative forms of assurance to at least some sections of the working population that, barring natural disasters and the unforeseen, they should be able to plan their lives with reasonable confidence. This includes consideration of different forms of labour flexibility, which can have very different implications for security; hence 'flexicurity' and other initiatives that will be discussed in the following chapters. New approaches are now needed for bringing together analysis of the full ensemble of issues affecting labour market policies, related social policies, class relations and industrial relations regimes, in terms of collective action games around the distribution of uncertainty. This can be tackled as a collective problem, in various ways, or it can be one of 'dumping' the uncertainty burden on different sections of the population. In the next chapter we shall develop an analytical scheme that tries to fulfil this aim. 